\title{
David Oliver: Health tourism, immigration, and the NHS
}

\author{
David Oliver consultant in geriatrics and acute general medicine
}

Berkshire

Results from a pilot scheme designed to clamp down on "health tourism" were reported by the London Evening Standard last month. ${ }^{1}$ As part of the scheme, which ran in 18 hospitals (11 in Greater London) over two months in autumn 2017, patients were required to show two forms of ID to prove that they were eligible for free NHS treatment. Checks carried out on 8894 patients found only 50 who were not eligible for free NHS treatment.

Overseas visitors are already eligible for free emergency care, and we have reciprocal arrangements with other EU countries for reimbursing healthcare costs, although the Public Accounts Committee did criticise the NHS in 2017 for a "chaotic approach" to chasing reimbursement from EU countries. ${ }^{2}$

One quoted example in the Standard, from Barts Hospital, illustrates the relatively small scale of the problem. Of 2752 renal outpatients only two were ineligible, and they were charged a total of $£ 2500$. St George’s Hospital checked 1660 maternity unit patients and found only 18 ineligible, with a total chargeable amount of $£ 45000$. Equally small proportions of ineligible maternity patients were found at Newham General and Redbridge Hospitals.

Checks carried out on 8894 patients found only 50 who were not eligible for free NHS treatment

Sadly, our national conversation is often led by emotive and distorted reporting. How did the Daily Mail report St George's maternity unit issues? "Crackdown on health tourist women who fly to the UK to give birth 'on the NHS' is WORKING despite fury of doctors' union [the BMA]."

The Daily Telegraph stated in 2017 that health tourism was costing the NHS $£ 2$ bn a year ${ }^{4}$ and said in 2016 that "NHS hit squads" would collect the cash.

The independent Full Fact site estimates that the cost of deliberate health tourism to the NHS is only around $£ 300 \mathrm{~m}$ a year. ${ }^{6}$ Such use - by people ineligible for free treatment who visit the UK to receive it-accounts for around $0.3 \%$ of the total NHS budget.

The government set out in 2016 an "ambition" to reclaim $£ 500 \mathrm{~m}$ a year from health tourism by the $2017-18$ financial year, ${ }^{7}$ but it predicts that this will be more like $£ 350 \mathrm{~m} .{ }^{6}$ Not negligible, but it's hardly going to save the NHS (total budget around $£ 122 \mathrm{bn})$ despite the rhetoric and headlines.

In primary care an agreement was signed in 2017 between the Department of Health, the Home Office, and NHS Digital to hand over information on patients registered with GPs, to help identify illegal immigrants. GPs understandably rejected the move, ${ }^{8}$ wanting to practise medicine rather than be immigration agents, as the "Docs Not Cops" movement has made clear. ${ }^{9}$ The arrangements were subsequently scrapped. ${ }^{10}$

Most immigrants to the UK are in their 20s or 30s, either working or paying to study, thus contributing to the funding of public services such as the NHS. ${ }^{11}{ }^{12}$ Rising healthcare costs are driven principally by people in mid- or late life with long term medical conditions.

Around one in five of the NHS's clinical workforce trained overseas. ${ }^{13}$ Until recently, we've happily recruited EU and non-EU staff at scale to supplement our homegrown workforce, especially in shortage specialties and deprived or remote regions. ${ }^{14}$ Home Office visa restrictions currently exclude many from coming here to fill pressing workforce gaps, and Brexit has made EU trained staff less keen on working here. ${ }^{1516}$

The Brexit "leave" vote was driven largely by voters' concerns about immigration, and the politicians and newspapers are playing to the gallery. But immigrants give far more to the NHS than they take from it.

Competing interests: See www.bmj.com/about-bmj/freelance-contributors/davidoliver

Provenance and peer review: Commissioned; not externally peer reviewed.

1 Lydall R. 8900 checks on NHS 'health tourists' find just 50 liable to pay. Evening Standard 29 May 2018. https://www.standard.co.uk/news/health/8900-checks-on-nhs-health-touristsfind-just-50-liable-to-pay-a3850121.html.

2 Donnelly L. NHS should charge health tourists "upfront" instead of chaotic debt chase. Telegraph 1 Feb 2017. https://www.telegraph.co.uk/news/2017/02/01/nhs-should-chargehealth-tourists-upfront-instead-chaotic-debt/.

3 Adams S. Crackdown on health tourist women who fly to the UK to give birth "on the NHS is WORKING despite fury of doctors' union. Mail Online 17 Dec 2017. www.dailymail.co. uk/news/article-5187057/Crackdown-pregnant-health-tourists-WORKING.html.

4 Donnelly L. "Health tourists" to be charged upfront for NHS care. Telegraph 20 Oct 2017. https://www.telegraph.co.uk/news/2017/10/20/nhs-ask-patients-bank-statements-checkqualify-free-health-care/. 
5 Donnelly L, Bodkin H. NHS hit squads to collect payment from health tourists. Telegraph 28 Oct 2016. https://www.telegraph.co.uk/news/2016/10/27/hit-squads-to-tackle-hospitalsnot-charging-payment-from-foreign/.

6 O'Leary J. Health tourism savings won't plug the hole in NHS funding. Full Fact 3 Feb 2017. https://fullfact.org/health/health-tourism-savings-wont-plug-hole-nhs-funding/.

7 National Audit Office. Recovering the cost of NHS treatment for overseas visitors. 28 Oct 2016. https://www.nao.org.uk/wp-content/uploads/2016/10/Recovering-the-cost-of-NHStreatment-for-overseas-visitors.pdf.

8 Hill R. Activists launch legal challenge against NHS patient data-sharing deal. Register 9 Nov 2017. https://www.theregister.co.uk/2017/11/09/ukgov_patient_data_sharing_deal_ challenged_by_campaign_groups/.

9 Docs Not Cops. www.docsnotcops.co.uk/.

10 Campbell D. NHS will no longer have to share immigrants' data with Home Office. Guardian 9 May 2018. https://www.theguardian.com/society/2018/may/09/government-to-stopforcing-nhs-to-share-patients-data-with-home-office.
11 Darvas Z. What is the age profile of UK immigrants? Bruegel 8 June 2016. http://bruegel. org/2016/06/what-is-the-age-profile-of-uk-immigrants/.

12 Rienzo C. Characteristics and outcomes of migrants in the UK labour market. 15 June 2018. http://www.migrationobservatory.ox.ac.uk/resources/briefings/characteristics-andoutcomes-of-migrants-in-the-uk-labour-market/.

13 Health Education England. Facing the facts, shaping the future: a draft workforce strategy for England 2027. 2017. https://bit.ly/2kKUuCL.

14 Simpson JM. Where are UK trained doctors? The migrant care law and its implications for the NHS-an essay by Julian M Simpson. BMJ 2018:361:k233610.1136/bmj.k2336.

15 lacobucci G. Home secretary announces review of visa cap. BMJ 2018;361:k247910.1136/bmj.k2479.

16 O'Dowd A. NHS recruitment from Europe is already falling because of Brexit, MPs are told. BMJ 2017;356:j96610.1136/bmj.j966.

Published by the BMJ Publishing Group Limited. For permission to use (where not already granted under a licence) please go to http://group.bmj.com/group/rights-licensing/ permissions 